\title{
Risk Factors for Breast Cancer: A Case-Control Study of 315 Women Followed in the Gynecology and Oncology Departments of Two University Teaching Hospitals in Yaounde, Cameroon
}

\author{
Felix Essiben ${ }^{1,2 *}$, Pascal Foumane ${ }^{1,3}$, Esther Ngo Um Meka1,3, Patience Signing Soh4, \\ Julius Dohbit Sama ${ }^{1}$, Eyongoben Osogo ${ }^{1}$, Emile Telesphore Mboudou ${ }^{1,2}$
}

\footnotetext{
${ }^{1}$ Department of Obstetrics and Gynecology, Faculty of Medicine and Biomedical Sciences (FMBS), University of Yaoundé I, Yaoundé, Cameroon

${ }^{2}$ Department of Obstetrics and Gynecology, Yaounde Central Hospital, Yaoundé, Cameroon

${ }^{3}$ Department of Obstetrics and Gynecology, Yaounde Gyneco-Obstetric and Pediatric Hospital, Yaoundé, Cameroon

${ }^{4}$ Higher Institute of Health, Université des Montagnes, Bagangte, Cameroon

Email: *essibenx@yahoo.com
}

How to cite this paper: Essiben, F., Foumane, P., Meka, E.N.U., Soh, P.S., Sama, J.D., Osogo, E. and Mboudou, E.T. (2016) Risk Factors for Breast Cancer: A CaseControl Study of 315 Women Followed in the Gynecology and Oncology Departments of Two University Teaching Hospitals in Yaounde, Cameroon. Open Journal of Obstetrics and Gynecology, 6, 676688.

http://dx.doi.org/10.4236/ojog.2016.612085

Received: August 25, 2016

Accepted: November 4, 2016

Published: November 7, 2016

Copyright $\odot 2016$ by authors and Scientific Research Publishing Inc. This work is licensed under the Creative Commons Attribution International License (CC BY 4.0).

http://creativecommons.org/licenses/by/4.0/

(c) (†) Open Access

\section{Abstract}

Introduction: Breast cancer is the most common cancer and the first cause of cancer-related deaths among women in Cameroon. The aim of the study was to investigate its risk factors for breast cancer at two University Teaching Hospitals in Yaoundé. Methodology: A case-control study was conducted for 5 months, from February 25th to July 25th 2015, at the Gynecology unit of the Yaoundé Gyneco-Obstetric and Pediatric Hospital (YGOPH) and the Medical Oncology unit of the Yaoundé General Hospital (YGH). One hundred and five patients with breast cancer (cases) were compared to 210 women who did not have breast cancer (controls). SPSS Version 18.0.0 software was used to analyze the data with a statistical significance considered at $\mathrm{P}$-value $<0.05$. Results: After univariate analysis, risk factors associated with breast cancer were: patient age $>50$ years $(\mathrm{P}<0.00$; $\mathrm{OR}=4.16$; $\mathrm{CI}=$ [2.50 - 7.14]); widowhood $(\mathrm{P}=0.001 ; \mathrm{OR}=3.45 ; \mathrm{CI}=[1.7-6.9])$, monthly income < 86 US dollars $(\mathrm{P}=0.002$; $\mathrm{OR}=2.19 ; \mathrm{CI}=[1,31-3.65])$, primary level of education $(\mathrm{P}=0.005 ; \mathrm{OR}=2.11 ; \mathrm{CI}=[1.25-3.56])$, consumption of red meat $>$ three times per week $(\mathrm{P}=0.002 ; \mathrm{OR}=2.14 ; \mathrm{CI}=[1.33-3.45])$, palm oil consumption $>$ two times per week $(\mathrm{P}=0.001 ; \mathrm{OR}=2.38 ; \mathrm{CI}=[1.4-4.1])$. After multivariate analysis, age $>50$ years $(\mathrm{aOR}=41.48 ; \mathrm{CI}=[2.46-69.9])$ and consumption of red meat $>$ three times per week $[\mathrm{aOR}=7.33$; $(1.49$ - 36) $]$ were the risk factors considered significant for breast cancer. Conclusion: Age $>50$ years and red meat consumption are indepen- 
dent risk factors for breast cancer at the Yaoundé General Hospital and at the Yaoundé Gyneco-Obstetric and Pediatric Hospital.

\section{Keywords}

Risk Factors, Breast Cancer, Red Meat, Cameroon

\section{Introduction}

Breast cancer is a major health problem worldwide, accounting for $16 \%$ of all cancers in women [1]

In the United States, it is the second most common cancer in women after skin cancer [2]. The incidence in France is 88 per 100,000 women making it the most common cancer in women [3].

The incidence of breast cancer is lowest in African countries, with an average of 19.3 per 100,000 women compared to 89.7 per 100,000 women in Europe [4]. However, this incidence has been increasing in developing countries. Although considered a disease of developed countries, in 2008 nearly $50 \%$ of all cases of breast cancer occurred in developing countries [5].

In Cameroon, the incidence of breast cancer is difficult to assess accurately. According to the 2012 Yaoundé cancer registry, 32\% of cancers in women involved the breast [6], making it the most common cancer in women in Cameroon. In 2014, Sando et al. at the Yaounde Gyneco-Obstetric and Pediatric Hospital (YGOPH) reported a 34\% prevalence of breast cancer, making it the second most common gynecological cancer after cervical cancer [7].

Worldwide, breast cancer mostly occurs after the age of 50 years [8] [9]. The situation is different in our context where it occurs at a relatively younger age, 46 years [7]. The majority of these cases in our setting are diagnosed at advanced stages of the disease because of difficulties in access to health care among other factors [9], underscoring the importance of early diagnosis through screening.

According to the WHO, breast cancer is responsible for $25 \%$ of cancer deaths in the world with the majority of these deaths occurring in the developing countries [8]. Although incidence of breast cancer is lowest in African countries, survival rates are also lowest [10]. The majority of breast cancer deaths, $69 \%$, occur in developing countries [11].

Risk factors for breast cancer are described in the literature. Increasing age, never married, widowed, nulliparity, smoking, alcohol use, low fruit and vegetable intake, a positive family history of breast cancer, post-menopausal use of hormone replacement therapy, early age at menarche or late menopause, great age at first pregnancy severe obesity were cited by authors as remarkable risk factors [12]-[15]. Danaei et al. in 2008 found that 7 million breast cancer related deaths worldwide were caused by nine potentially modifiable risk factors [16]. They designated tobacco smoking, alcohol consump- 
tion and low fruit and vegetables intake as risk factors for low-and-middle income countries.

In Cameroon, few data are available on breast cancer associated risk factors. Epidemiological data including some nutritional risk factors for breast cancer remain insufficient.

Some studies have incriminated feeding habits in the induction of cancers in general [17] [18] and breast cancer in particular [19] [20]. Westernization of lifestyles of people in the developing countries can partially explain this increase in the incidence of breast cancer [21]. Overweight and obesity are modifiable risk factors for cancer related deaths [16].

The aim of this study was to look for risk factors for breast cancer in patients treated for breast cancer at two university teaching hospitals in Yaoundé. The findings of this study could help improve the preventive methods based on the modifiable risk factors identified.

\section{Methods}

For 5 months, from February to July 2015, a case-control study was conducted in the gynecology unit of the Yaoundé Gyneco-Obstetric and Pediatric Hospital (YGOPH) and the Medical Oncology unit of the Yaoundé General Hospital (YGH). We compared women treated for breast cancer (cases) with women who did not have breast cancer (controls).

We obtained the approval of the protocol for the study from the ethical committee of the YGOPH and YGH. Cases were recruited from the departments concerned. Their medical records were consulted. Controls were recruited randomly from the outpatient departments of the same hospitals. All women who gave their free and informed consent were interviewed by an investigator and examined. The data collection was done using a pretested questionnaire. Pregnant women were excluded from the study.

The variables of interest were: age, level of education, marital status, income level, family and or personal history of breast cancer, the existence of another cancer in the family, age at menarche, age at first pregnancy, parity, duration of breastfeeding, a past history of use of hormonal contraception and hormone replacement therapy, duration of hormonal contraception use, infertility, menopause, benign breast pathology, alcohol and tobacco consumption, physical activity, obesity, diet (consumption of vegetables, leguminous plants, red meat, fish, conserves, palm oil, refined oil).

The calculated minimal sample size was 23 subjects for each group based on $34 \%$ prevalence of breast cancer in Cameroon [22] and according to the Schlesselman formula [23]. The chosen precision for statistical calculations was $5 \%$. To enhance the strength of association, we considered one case for two controls.

We analyzed the data using Epi Info 3.5.4 software and Microsoft Excel 2010. The differences between proportions were analyzed using contingency tables and by applying the Khi-square test. A P-value $<0.05$ was considered to be statistically significant. The association between variables was assessed by calculating the Odds Ratio (OR) with 
a confidence interval (CI) of 95\%. Logistic regression was used to eliminate confounding factors and all variables with $\mathrm{p}<0.02$ were included in the regression model.

\section{Results}

During the five months recruitment period, we studied 315 women from the two services. 105 cases were compared with 210 controls. The mean age of the cases $(49 \pm 13$ years) was statistically different $(\mathrm{P}<0.001)$ from that of the controls $(40 \pm 12$ years $)$. The women in both groups were more often married, with low income level and had secondary level education (Table 1). The socio-demographic risk factors found (Table 1) were: age groups $[50-60](\mathrm{P}=0.012 ; \mathrm{OR}=2.14 ; \mathrm{CI}=1.17-3.9),[60-70](\mathrm{P}=$ $0.002 ; \mathrm{OR}=4.93 ; \mathrm{CI}=2.15$ - 11.34) and $[70-88](\mathrm{P}=0.02 ; \mathrm{OR}=12.6 ; \mathrm{CI}=1.5$ 106.7), widowhood $(\mathrm{P}=0.006 ; \mathrm{OR}=3.45 ; \mathrm{CI}=1.7-6.9])$, monthly income level $<86$ US dollars $(\mathrm{P}=0.002 ; \mathrm{OR}=2.19 ; \mathrm{CI}=1.31-3.65)$, primary education level $(\mathrm{P}=0.005$,

Table 1. Comparison of socio-demographic variables among women with breast cancer (cases, $\mathrm{n}=105)$ and those without breast cancer (controls, $\mathrm{n}=210$ ).

\begin{tabular}{|c|c|c|c|c|}
\hline Variables & Cases n (\%) & Controls n (\%) & OR (CI 95\%) & $\mathbf{P}$ \\
\hline \multicolumn{5}{|c|}{ Age group (years) } \\
\hline$[20-30]$ & $8(27.6)$ & $35(16.7)$ & $0.42(0.18-0.92)$ & 0.031 \\
\hline$[30-40]$ & $27(25.7)$ & $80(38.1)$ & $0.56(0.33-0.94)$ & 0.03 \\
\hline$[40-50]$ & $20(19.0)$ & $57(27.1)$ & $0.63(0.36-1.12)$ & 0.117 \\
\hline$[50-60]$ & $25(23.9)$ & $28(13.3)$ & $2.14(1.17-3.9)$ & 0.012 \\
\hline$[60-70]$ & $19(18.0)$ & $9(4.3)$ & $4.93(2.15-11.34)$ & 0.002 \\
\hline$[70-88]$ & $6(5.7)$ & $1(0.5)$ & $12.6(1.5-106.7)$ & 0.02 \\
\hline \multicolumn{5}{|c|}{ Marital status } \\
\hline Single & $24(22.9)$ & $65(31.0)$ & $0.66(0.38-1.14)$ & 0.134 \\
\hline Married & $47(44.8)$ & $100(47.6)$ & $0.89(0.56-1.14)$ & 0.63 \\
\hline Divorced & $4(3.8)$ & $6(2.9)$ & $1.34(0.37-4.8)$ & 0.65 \\
\hline Widow & $22(20.9)$ & $15(7.1)$ & $3.45(1.7-6.9)$ & 0.006 \\
\hline Co-habitation & $8(7.6)$ & $24(1.4)$ & $0.64(0.27-1.4)$ & 0.29 \\
\hline \multicolumn{5}{|c|}{ Income level (US dollars) } \\
\hline$<86$ & $45(52.3)$ & $71(37.9)$ & $2.19(1.31-3.65)$ & 0.002 \\
\hline$[86-172]$ & $18(20.9)$ & $57(30.4)$ & $0.60(0.33-1.11)$ & 0.102 \\
\hline [172 - 258] & $10(11.6)$ & $22(11.7)$ & $1.01(0.46-2.45)$ & 0.97 \\
\hline [258 - 344] & $7(8.1)$ & $22(11.7)$ & $0.99(0.44-2.17)$ & 0.97 \\
\hline [344 - 516] & $3(3.4)$ & $8(4.2)$ & $0.81(0.21-3.13)$ & 0.76 \\
\hline$>516$ & $3(3.4)$ & $7(3.7)$ & $0.93(0.23-3.68)$ & 0.92 \\
\hline \multicolumn{5}{|c|}{ Level of education } \\
\hline None & $10(9.5)$ & $9(4.2)$ & $3.35(0.92-5.98)$ & 0.073 \\
\hline Primary & $37(35.2)$ & $43(20.5)$ & $2.11(1.25-3.56)$ & 0.005 \\
\hline Secondary & $47(44.8)$ & $107(51.0)$ & $0.78(0.49-1.25)$ & 0.301 \\
\hline Higher education & $11(10.5)$ & $51(24.3)$ & $0.36(0.18-0.73)$ & 0.005 \\
\hline
\end{tabular}

OR: Odds Ratio. CI: Confidence Interval. \%: Percentage. 
$\mathrm{OR}=2.11 ; \mathrm{CI}=1.25-3.56)$,

Most of our patients in the two groups were multiparous and had more often practiced breastfeeding, $84.4 \%$ and $81.4 \%$ respectively in cases and controls. Duration of breastfeeding $>96$ months $(\mathrm{P}=0.01$; $\mathrm{OR}=2.65 ; \mathrm{CI}=1.59-4.39)$ was founded to be a risk factor (Table 2). Concerning other personal history such as age at menarche, previous breast pathology, personal history and family history of breast cancer, none was contributive as well as alcohol and tobacco consumption, physical activity and obesity (Table 2).

The unhealthy dietary habits identified were (Table 3 ): red meat consumption $>3$ times weekly $(\mathrm{P}=0.002 ; \mathrm{OR}=2.14 ; \mathrm{CI}=1.33-3.45)$; consumption of palm oil $>2$ times per week $(\mathrm{P}=0.001 ; \mathrm{OR}=2.38 ; \mathrm{CI}=1.4-4.1)$.

Protective factors for breast cancer were (Table 1 and Table 2): menopause ( $\mathrm{P}=$ 0.002 ; $\mathrm{OR}=0.37 ; \mathrm{CI}=0.22-0.62])$, nulliparity $(P=0.008 ; \mathrm{OR}=0.46 ; \mathrm{CI}=0.26-0.08)$ and the higher level of education $(\mathrm{P}=0.005$; $\mathrm{OR}=0.36$; $\mathrm{CI}=0.18-0.73)$.

After multivariate analysis, the risk factors for breast cancer identified were (Table 4): age $>50$ years $(\mathrm{P}=0.010 ; \mathrm{aOR}=41.48 ; \mathrm{CI}=2.46-699.1)$ and heavy consumption of red meat $(\mathrm{P}=0.014 ; \mathrm{aOR}=7.33 ; \mathrm{CI}=1.49-36)$.

\section{Discussion}

In Cameroon, breast cancer onset is usually between the ages of 35 to 50 years [6] implying that the mean age at diagnosis is significantly below 50 years. Also breast cancer is often diagnosed in advanced stages of the condition [7], implying an insidious onset to the disease long before presentation at the hospital. Although breast cancer onset is before 50years, we found out that the risk was greatest in patients above 50 years. This result is similar to findings by Nkondjock et al. [24] who found an increased risk of $7.1 \%$ between 50 and 74 years. Nevertheless, previous studies in our setting show that the average age of patients with breast cancer at diagnosis was lower than 50 years [7] [25]. This suggests involvement of other factors independent of patients' ages.

Iraj et al. in Iran reported that breast cancer was diagnosed with advanced lesions in patients presenting at a state-owned hospital, and in low-income earners [26]. We carried out our study in two state-owned hospitals that manage the majority of cancer cases due to their relatively low treatment costs. Low purchasing power is a factor limiting access to health care. Income level $<86$ dollars was identified as a risk factor for breast cancer. Low income is associated with low levels of education which was significantly associated with breast cancer in our study. Landolsi et al. in Tunisia found that most patients with breast cancer had low levels of education [27]. Breast cancer is often diagnosed at an advanced stage [9] corresponding to women who do not have easy access to health care. Conversely, Nkondjock et al. found that the risk of breast cancer is slightly increased in high income earners because they tend to carry fewer pregnancies or have children at an older age [24]. Mandana et al. found that women who had never been married before and widows were at increased risk for breast cancer [13]. Widowhood was not found to be an independent risk factor in our study despite the fact 
Table 2. Comparing the history of women with breast cancer (cases, $n=105$ ) with those of women without breast cancer (controls, $\mathrm{n}=210$ ).

\begin{tabular}{|c|c|c|c|c|}
\hline Variable & $\begin{array}{l}\text { Cases } \\
\text { n (\%) }\end{array}$ & $\begin{array}{c}\text { Controls } \\
\text { n (\%) }\end{array}$ & OR (CI 95\%) & $\mathbf{P}$ \\
\hline \multicolumn{5}{|c|}{ Past history of breast cancer } \\
\hline Yes & $21(20)$ & $52(24.8)$ & $1.31(0.74-2.32)$ & \multirow{2}{*}{0.378} \\
\hline \multirow[t]{2}{*}{ No } & $84(80)$ & $158(75.2)$ & $0.76(0.43-1.34)$ & \\
\hline & \multicolumn{4}{|c|}{ Past history of other cancers } \\
\hline Yes & $16(15.2)$ & $34(16.2)$ & $1.07(0.56-2.04)$ & \multirow{2}{*}{0.83} \\
\hline No & $89(84.8)$ & $176(83.8)$ & $0.93(0.49-1.78)$ & \\
\hline \multicolumn{5}{|c|}{ Breast pathology } \\
\hline Yes & $16(15.2)$ & $17(8.1)$ & $0.49(0.23-1.03)$ & \multirow{2}{*}{0.051} \\
\hline No & 89 (84.) & $193(91.9)$ & $2.04(0.97-4.22)$ & \\
\hline \multicolumn{5}{|c|}{ Parity } \\
\hline 0 & $19(18.1)$ & $68(32.4)$ & $0.46(0.26-0.82)$ & 0.008 \\
\hline $1-2$ & $12(11.4)$ & $31(14.7)$ & $0.74(0.36-1.51)$ & 0.41 \\
\hline $3-5$ & $47(44.8)$ & $76(36.2)$ & $1.43(0.89-2.3)$ & 0.14 \\
\hline$>5$ & $27(25.7)$ & $35(16.7)$ & $1.73(0.98-3.1)$ & 0.059 \\
\hline \multicolumn{5}{|c|}{ Age at menarche } \\
\hline$<12$ years & $11(10.5)$ & $35(16.7)$ & $0.58(0.28-1.2)$ & 0.146 \\
\hline $12-14$ years & $42(40)$ & $91(43.3)$ & $0.87(0.54-1.4)$ & 0.57 \\
\hline $14-16$ years & $38(36.2)$ & $62(29.5)$ & $1.35(0.82-2.22)$ & 0.23 \\
\hline$>16$ years & $14(13.3)$ & $22(10.5)$ & $1.31(0.64-2.67)$ & 0.45 \\
\hline \multicolumn{5}{|c|}{ Hormonal contraception } \\
\hline Yes & $33(31.4)$ & $54(25.7)$ & $0.75(0.81-1.26)$ & 0.285 \\
\hline No & $72(68.6)$ & $156(74.3)$ & $1.32(0.79-1.22)$ & \\
\hline \multicolumn{5}{|c|}{ Duration of hormonal contraception } \\
\hline$<24$ months & $18(17.1)$ & $39(18.5)$ & $0.46(0.17-1.14)$ & 0.95 \\
\hline 24 - 60 months & $8(7.6)$ & $11(5.2)$ & $1.27(0.44-3.52)$ & 0.67 \\
\hline $60-120$ months & $7(6.6)$ & $4(1.9)$ & $3.36(0.9-12.57)$ & 0.071 \\
\hline \multicolumn{5}{|c|}{ Menopause } \\
\hline Yes & $44(41.9)$ & $45(21.4)$ & $0.37(0.22-0.62)$ & \\
\hline No & $61(58.1)$ & $165(78.6)$ & $2.65(1.59-4.39)$ & 0.002 \\
\hline \multicolumn{5}{|c|}{ Breastfeeding } \\
\hline Yes & $89(84.8)$ & $171(81.4)$ & $0.78(0.41-1.49)$ & \\
\hline No & $16(15.2)$ & $39(18.6)$ & $1.27(0.67-0.40)$ & 0.46 \\
\hline \multicolumn{5}{|c|}{ Duration of breastfeeding } \\
\hline $1-12$ months & $8(8.9)$ & $24(14.1)$ & $0.61(0.26-1.41)$ & 0.244 \\
\hline $12-24$ months & $14(15.7)$ & $33(19.2)$ & $0.78(0.39-1.55)$ & 0.49 \\
\hline $24-48$ months & $20(22.4)$ & $48(28.0)$ & $0.74(0.41-1.35)$ & 0.33 \\
\hline $48-72$ months & $18(20.2)$ & $35(20.4)$ & $0.98(0.52-1.86)$ & 0.96 \\
\hline
\end{tabular}


Continued

\begin{tabular}{|c|c|c|c|c|}
\hline 72 - 96 months & $11(12.3)$ & $16(9.3)$ & $1.37(0.61-3.10)$ & 0.45 \\
\hline$>96$ months & $18(20.2)$ & $15(8.7)$ & $2.65(1.59-4.39)$ & 0.01 \\
\hline \multicolumn{5}{|c|}{ Alcohol consumption } \\
\hline Yes & $64(60.9)$ & $148(70.5)$ & $1.63(0.9-2.70)$ & \\
\hline No & $41(39.1)$ & $59(28.5)$ & $0.61(0.37-1.01)$ & 0.052 \\
\hline \multicolumn{5}{|c|}{ Smoking Tobacco } \\
\hline Yes & $12(11.4)$ & $12(5.7)$ & $0.46(0.20-1.08)$ & \\
\hline No & $93(88.6)$ & $198(94.3)$ & $2.13(0.92-4.92)$ & 0.072 \\
\hline \multicolumn{5}{|c|}{ Physical activity } \\
\hline Yes & $50(47.6)$ & $101(49.1)$ & $1.02(0.63-1.63)$ & 0.936 \\
\hline No & $55(52.4)$ & $109(51.9)$ & $0.98(0.61-1.57)$ & \\
\hline \multicolumn{5}{|c|}{ Obesity } \\
\hline Yes & $67(63.8)$ & $129(61.4)$ & $0.90(0.55-147)$ & \\
\hline No & $38(36.2)$ & $81(38.6)$ & $1.11(0.68-1.8)$ & 0.460 \\
\hline
\end{tabular}

OR: Odds Ratio. CI: Confidence Interval. \%: Percentage.

Table 3. Comparison of dietary habits of women with breast cancer (cases, $n=105$ ) and those without breast cancer (controls, $\mathrm{n}=210$ ).

\begin{tabular}{|c|c|c|c|c|}
\hline Variable & Cases n (\%) & Controls n (\%) & OR (CI 95\%) & $\mathbf{P}$ \\
\hline \multicolumn{5}{|l|}{ Vegetables } \\
\hline$\leq 2$ times/week & $65(61.9)$ & $139(66.2)$ & $0.3(0.51-1.35)$ & \multirow{2}{*}{0.450} \\
\hline$>2$ times/week & $40(38.1)$ & $71(33.8)$ & $1.2(0.74-1.96)$ & \\
\hline \multicolumn{5}{|l|}{ Leguminous plant } \\
\hline$\leq 3$ times/week & $68(64.8)$ & $140(66.7)$ & $0.9(0.56-1.51)$ & \multirow{2}{*}{0.730} \\
\hline$>3$ times/week & $37(35.2)$ & $70(33.3)$ & $1.1(0.66-1.78)$ & \\
\hline \multicolumn{5}{|l|}{ Red meat } \\
\hline$\leq 3$ times/week & $49(46.7)$ & $137(65.2)$ & $046(0.28-075)$ & \multirow{2}{*}{0.002} \\
\hline$>3$ times/week & $56(53.3)$ & $73(34.8)$ & $2.14(1.33-3.45)$ & \\
\hline \multicolumn{5}{|l|}{ Fish } \\
\hline$\leq 3$ times/week & $61(58.1)$ & $113(53.8)$ & $1.19(0.74-1.92)$ & \multirow{2}{*}{0.470} \\
\hline$>3$ times/week & $44(41.9)$ & $97(46.2)$ & $0.84(0.52-1.35)$ & \\
\hline \multicolumn{5}{|l|}{ Conserves } \\
\hline Yes & $5(4.8)$ & $20(9.5)$ & $0.47(0.17-1.29)$ & \multirow{2}{*}{0.140} \\
\hline No & $100(95.2)$ & $190(90.5)$ & $2.1(0.77-578)$ & \\
\hline \multicolumn{5}{|l|}{ Palm oil } \\
\hline$\leq 2$ times/week & $24(22.9)$ & $87(41.4)$ & $0.42(0.24-0.71)$ & \multirow{2}{*}{0.001} \\
\hline$>2$ times/week & $81(77.1)$ & $123(58.6)$ & $2.38(1.4-4.1)$ & \\
\hline \multicolumn{5}{|l|}{ Refined oil } \\
\hline$\leq 4$ times/week & $64(60.9)$ & $105(50)$ & $1.56(0.97-2.56)$ & \\
\hline$>4$ times/week & $41(39.1)$ & $105(50)$ & $0.64(0.39-1.03)$ & 0.066 \\
\hline
\end{tabular}

OR: Odds Ratio. CI: Confidence Interval. \%: Percentage. 
Table 4. Logistic regression.

\begin{tabular}{ccc}
\hline Variable & OR (CI 95\%) & P \\
\hline Age $>$ 50 ans & $41.48(2.46-699.1)$ & 0.010 \\
Monthly income < 86 US dollars & $1.34(0.22-7.95)$ & 0.749 \\
Higher education level & $7.5(0.66-86.0)$ & 0.104 \\
Heavy red meat consumption & $7.33(1.49-36.0)$ & 0.014 \\
Heavy Palm oil consumption & $3.02(0.6-15.0)$ & 0.177 \\
Refined oil & $0.76(0.17-3.47)$ & 0.721 \\
Tinned food & $1.55(0.08-30.84)$ & 0.775 \\
Past history of breast pathology & $0.63(0.07-5.9)$ & 0.686 \\
Alcohol consumption & $0.42(0.09-1.9)$ & 0.260 \\
Tabacco smoking & $2.02(0.14-29.48)$ & 0.607 \\
Parity < 2 & $182(0.6-55.0)$ & 0.096 \\
Menopause & $0.076(0.00-1.32)$ & 0.077 \\
Widowhood & $1.15(0.09-14.9)$ & 0.917 \\
\hline Duration of brestfeeding $>$ 96 months & $0.28(0.03-2.8)$ & 0.279 \\
\hline
\end{tabular}

OR: Odds Ratio. CI: Confidence Interval. \%: Percentage.

that widows were the most represented group of women who have had breast cancer. This status is probably a confounding factor because most widows are often older than 50 years.

Our findings reveal that lifestyle modifications could be a risk factor for breast cancer. Consuming palm oil more than 2 times per week was significantly associated with breast cancer occurrence. This finding is specific to our setting because of the frequency of consumption of the product. Palm oil is a food substance which is financially very accessible and rich in unsaturated fatty acids. It is rich in beta carotene, a precursor for vitamin $\mathrm{A}$ and $\mathrm{E}$, and known to have anti-carcinogenic properties. However, during cooking, the oil is usually heated and bleached thereby converting the unsaturated fatty acids are converted to saturated fatty acids. Beta carotene is thus destroyed eliminating its anti-carcinogenic properties hence our findings. Bougnoux et al. in 2010 reported the involvement of saturated fatty acids in promoting breast cancer carcinogenesis [28]. Contrary to our findings however, Arab et al. [29] in 2016 disputed the involvement of conjugated fatty acids in breast cancer carcinogenesis based on their systematic review of studies concerning the issue.

Red meat consumption $>3$ times weekly is an independent risk factor for breast cancer. This result is consistent with that of Farvid et al. in 2014 in the United States who found that eating red meat more than 5 times a week significantly increased breast cancer risk in contrast to those who consumed meat less than five times weekly [30]. Beef consumption in our setting is usually done after cooking at high temperatures and often following coal grilling. Steck et al. had described that beef cooked this way increased breast cancer risk [31]. The substances deemed carcinogenic are usually expressed when meat is heated to high temperatures [32]. 
Although to varying degrees, some reproduction-related factors have been identified as risk factors for breast cancer. Some authors had reported a decreased risk of breast cancer with increasing parity [33]-[35]. Nulliparity in our study was found to be a risk factor. However, w with co-existing factors, parity appears to be a factor of confusion for breast cancer in our setting. This is probably because breast cancer is increasingly occuring in younger women [7] who are often nulliparous. Multiparity was not identified as a risk factor. Palmer et al. found out that in breastfeeding women, parity-related risks were eliminated hence implying that breastfeeding conferred protection against the disease [34]. This is especially because grand multiparae were women who breastfed their babies longest.

We could not find any correlations between breastfeeding and breast cancer. This finding is coherent with findings by Magnusson et al. [33]. However in breastfeeding women, duration of breastfeeding $>96$ months was found to be a risk factor contrary to descriptions in literature where breastfeeding is a protective factor [16] [35]. Ortiz Mendoza et al. in Mexico found that women younger than 50 who have breast cancer had short lactation times at less than 12 months [36].

Early onset of puberty was not identified as a risk factor in our setting. Literature describes that prolonged exposure to estrogens including precocious puberty, increases the risk of breast cancer [20] especially because early maternity constitutes a significant protective factor [35].

Menopause was not found to be a risk factor in this study because breast cancer occurs in our environment at a young age, before menopause [7]. This correlates with the findings of Magnusson et al. who found no association between menopausal symptoms and breast-cancer risk [33].

Danaei G. et al. in 2008 found that alcohol consumption and tobacco smoking play a significant role in carcinogenesis [16]. We did not find a similar result because tobacco consumption is not common amongst women in our context. This is also true for alcohol consumption which appears to be marginal amongst women in our setting. Furthermore, the relationship between alcohol and breast cancer appears to be related to the amount of alcohol consumed [37] [38]. In a 2014 study in 3 African countries, Qian et al. reported a significantly higher risk of breast cancer among women consuming alcohol at least once a day for at least six months [39].

A family history of breast cancer or other type of cancer was not found to be a risk factor in our study. According to the American Cancer Society [40], 50\% of breast cancers occur in women with no known risk factors. However, when there is a positive family history, the closer the relationship the greater the risk [41].

Our results do have their limitations though. Due to our limited financial resources, we were unable to perform a mammogram to rule out the presence of cancerous lesions in the control group. Furthermore, an information bias is possible in both groups, as far as recall on food habits and women's lifestyles may be concerned.

\section{Conclusion}

We found a wide variety of risk factors. Age $>50$ years and beef consumption were in- 
dependent risk factors for breast cancer identified in this study. These factors should be considered when carrying out primary prevention of breast cancer in our context.

\section{Acknowledgements}

We acknowledge the administrative staff of the Yaoundé General Hospital and the Yaoundé Gyneco-Obstetric and Pediatric Hospital for facilitating the implementation of this study as well as the personnel of these hospitals for their support during the collection of data. Apart from the personal contribution of each author, the study was not funded.

\section{Conflict of Interest}

The authors declare no conflict of interests

\section{Authors' Contributions}

Essiben F., Foumane P., Signing Soh P. conceived the study, participated in the study design, data collection and drafting the manuscript. Ngo Um Meka E. has been involved in analysis and interpretation of data. Eyongoben O. participated in data collection and review of the article. Dohbit proof-read the manuscript. Mboudou T. E. supervised the study. All authors have read and approved the final manuscript.

\section{References}

[1] Global Burden of Disease Cancer Collaboration (2015) The Global Burden of Cancer 2013. JAMA Oncology, 1, 505-527. http://dx.doi.org/10.1001/jamaoncol.2015.0735

[2] DeSantis, C., Ma, J., Bryan, L. and Jemal, A. (2014) Breast Cancer Statistics. Cancer Journal for Clinicians, 64, 52-62. http://dx.doi.org/10.3322/caac.21203

[3] National Institute for Cancer (2016) Epidemiology of Cancers. (In French) http://www.e-cancer.fr/Professionnels-de-sante/Les-chiffres-du-cancer-en-France/Epidemi ologie-des-cancers

[4] Global Health Estimates, WHO (2013) Breast Cancer: Prevention and Control. http://www.who.int/cancer/detection/breastcancer/en/index1.html

[5] International Agency for Research on Cancer (IARC) (2010) World Cancer Report 2008. 42-43. https://www.iarc.fr/en/media-centre/iarcnews/2010/globocan2008.php

[6] Enow Orock, G.E., Ndom, P. and Doh, A.S. (2012) Current Cancer Incidence and Trends in Yaounde, Cameroon. Oncology, Gastroenterology and Hepatology Reports, 1, 58-63. http://www.oghreports.org/sites/default/files/OncGasHepRep_2012_1_2_58_133639.pdf

[7] Sando, Z., Fouogue, J., Fouelifack, F., Fouedjio, J., Mboudou, E. and Oyono, J. (2014) Profil des cancers gynécologiques et mammaires à Yaoundé-Cameroun. The Pan African Medical Journal, 17, 37-47. http://dx.doi.org/10.11604/pamj.2014.17.28.3447

[8] WHO (2015) Breast Cancer: Prevention and Control. http://www.who.int/cancer/detection/breastcancer/en/index1.html

[9] Dickens, C., Joffe, M., Jacobson, J., Venter, F., Schüz, J., Cubasch, H. and McCormack, V. (2014) Stage at Breast Cancer Diagnosis and Distance from Diagnostic Hospital in a Periurban Setting: A South African Public Hospital Case Series of Over 1,000 Women. International Journal of Cancer, 135, 2173-2182. http://dx.doi.org/10.1002/ijc.28861 
[10] Coleman, M.P., Quaresma, M., Berrino, F., Lutz, J.M., De Angelis, R., Capocaccia, R., Baili, P., Rachet, B., Gatta, G., Hakulinen, T., Micheli, A., Sant, M., Weir, H.K., Elwood, J.M., Tsukuma, H., Koifman, S., E Silva, G.A., Francisci, S., Santaquilani, M., Verdecchia, A., Storm, H.H., Young, J.L. and CONCORD Working Group (2008) Cancer Survival in Five Continents: A Worldwide Population-Based Study (CONCORD). Lancet Oncology, 9, 730756. http://dx.doi.org/10.1016/S1470-2045(08)70179-7

[11] Ferlay, J., Soerjomataram, I., Dikshit, R., Eser, S., Mathers, C., Rebelo, M., Parkin, D.M., Forman, D. and Bray, F. (2015) Cancer Incidence and Mortality Worldwide: Sources, Methods and Major Patterns in GLOBOCAN 2012. International Journal of Cancer, 136, 359386. http://dx.doi.org/10.1002/ijc.29210

[12] Lacey Jr., J.V., Kreimer, A.R., Buys, S.S., Marcus, P.M., Chang, S.C., Leitzmann, M.F., Hoover, R.N., Prorok, P.C., Berg, C.D., Hartge, P. and Prostate, Lung, Colorectal and Ovarian (PLCO) Cancer Screening Trial Project Team (2009) Breast Cancer Epidemiology According to Recognized Breast Cancer Risk Factors in the Prostate, Lung, Colorectal and Ovarian (PLCO) Cancer Screening Trial Cohort. BMC Cancer, 9, 84. http://dx.doi.org/10.1186/1471-2407-9-84

[13] Ebrahimi, M., Vahdaninia, M. and Montazeri, A. (2002) Risk Factors for Breast Cancer in Iran: A Case-Control Study. Breast Cancer Research, 4, R10. http://dx.doi.org/10.1186/bcr454

[14] Sifuentes-Álvarez, A., Castañeda-Martínez, L.Y., Lugo-Nevares, M. and Reyes-Romero, M.A. (2015) [Risk Factors Associated with Breast Cancer Women's in Durango, Mexico]. Ginecologia y Obstetricia de Mexico, 83, 662-669. (In Spanish)

[15] Ewertz, M. and Duffy, S.W. (1998) Risk of Breast Cancer in Relation to Reproductive Factors in Denmark. British Journal Cancer, 58, 99-104. http://dx.doi.org/10.1038/bjc.1988.172

[16] Danaei, G., Vander Hoorn, S., Lopez, A.D., Murray, C.J., Ezzati, M. and Comparative Risk Assessment Collaborating Group (Cancers) (2005) Causes of Cancer in the World: Comparative Risk Assessment of Nine Behavioural and Environmental Risk Factors. The Lancet, 366, 1784-1793. http://dx.doi.org/10.1016/S0140-6736(05)67725-2

[17] Jolfaie, N.R., Mirzaie, S., Ghiasvand, R., Askari, G. and Miraghajani, M. (2015) The Effect of Glutamine Intake on Complications of Colorectal and Colon Cancer Treatment: A Systematic Review. Journal of Research in Medical Sciences, 20, 910-918. http://dx.doi.org/10.4103/1735-1995.170634

[18] Golpour, S., Rafie, N., Safavi, S.M. and Miraghajani, M. (2015) Dietary Isoflavones and Gastric Cancer: A Brief Review of Current Studies. Journal of Research in Medical Sciences, 20, 893-900. http://dx.doi.org/10.4103/1735-1995.170627

[19] Zheng, J.S., Hu, X.J., Zhao, Y.M., Yang, J. and Li, D. (2013) Intake of Fish and Marine n-3 Polyunsaturated Fatty Acids and Risk of Breast Cancer: Meta-Analysis of Data from 21 Independent Prospective Cohort Studies. British Medical Journal, 346, f3706. http://dx.doi.org/10.1136/bmj.f3706

[20] Xie, Q., Chen, M.L., Qin, Y., Zhang, Q.Y., Xu, H.X., Zhou, Y., Mi, M.T. and Zhu, J.D. (2013) Isoflavone Consumption and Risk of Breast Cancer: A Dose-Response Meta-Analysis of Observational Studies. Asia Pacific Journal of Clinical Nutrition, 22, 118-127.

[21] Porter, P. (2008) “Westernizing” Women's Risks? Breast Cancer in Lower-Income Countries. The New England Journal Medicine, 358, 213-216. http://dx.doi.org/10.1056/NEJMp0708307

[22] International Agency for Research on Cancer (2010) Globocan Cameroun Fact Sheets: Breast Cancer. Lyon France. http://globocan.iarc.fr/

[23] Schlesselman, J.J. (1974) Sample Size Requirements in Cohort and Case-Control Studies of 
Disease. American Journal of Epidemiology, 99, 381-384.

[24] Nkondjock, A. and Ghadirian, P. (2005) [Risk Factors and Risk Reduction of Breast Cancer]. Médecine Sciences, 21, 175-180. (In French) http://dx.doi.org/10.1051/medsci/2005212175

[25] Essiben, F., Foumane, P., Mboudou, E., Dohbit, J., Mve Koh, V. and Ndom, P. (2013) [Diagnosis and Treatment of Breast Cancer in Cameroon: A Series of 65 Cases]. Mali Médical, 28, 1-5. (In French)

[26] Harirchi, I., Karbakhsh, M., Hadi, F., Madani, S.S., Sirati, F. and Kolahdoozan, S. (2015) Patient Delay, Diagnosis Delay and Treatment Delay for Breast Cancer: Comparison of the Pattern between Patients in Public and Private Health Sectors. Archives of Breast Cancer, 2, 52-57.

[27] Landolsi, A., Gahbiche, S., Chaafii, R., Chabchoub, I., Fatma, L., Hochlef, M., Gharbi, O. and Ben Ahmed, S. (2010) [Reasons of Diagnostic Delay of Breast Cancer in Tunisian Women (160 Patients in the Central Region of Tunisia)]. La Tunisie Médicale, 88, 894-897. (In French)

[28] Bougnoux, P., Hajjaji, N. and Couet, C. (2010) [Lipids and Breast Cancer: From Prevention to Treatment]. Médecine Clinique Endocrinologie \& Diabète, 45, 42-45. (In French) http://www.mced.fr/assets/files/article/45/SyntheseBougnoux-45F.pdf

[29] Arab, A., Akbarian, S.A., Ghiyasvand, R. and Miraghajani, M. (2016) The Effects of Conjugated Linoleic Acids on Breast Cancer: A Systematic Review. Advanced Biomedical Research, 5, 115. http://dx.doi.org/10.4103/2277-9175.185573

[30] Farvid, M., Cho, E., Chen, W., Eliassen, A. and Willett, W. (2014) Dietary Protein Sources in Early Adulthood and Breast Cancer Incidence: Prospective Cohort Study. British Medical Journal, 348, 3437-3438. http://dx.doi.org/10.1136/bmj.g3437

[31] Steck, S.E., Gaudet, M.M., Eng, S.M., Britton, J.A., Teitelbaum, S.L., Neugut, A.I., Santella, R.M. and Gammon, M.D. (2007) Cooked Meat and Risk of Breast Cancer-Lifetime versus Recent Dietary Intake. Epidemiology, 18, 373-382. http://dx.doi.org/10.1097/01.ede.0000259968.11151.06

[32] De Stefani, E., Ronco, A., Mendilaharsu, M., Guidobono, M. and Deneo-Pellegrini, H. (1997) Meat Intake, Heterocyclic Amines, and Risk of Breast Cancer: A Case-Control Study in Uruguay. Cancer Epidemiology, Biomarkers and Prevention, 6, 573-581.

[33] Magnusson, C.M., Persson, I.R., Baron, J.A., Ekbom, A., Bergström, R. and Adami, H.O. (1999) The Role of Reproductive Factors and Use of Oral Contraceptives in the Aetiology of Breast Cancer in Women Aged 50 to 74 Years. International Journal of Cancer, 80, 231236.

http://dx.doi.org/10.1002/(SICI)1097-0215(19990118)80:2<231::AID-IJC11>3.0.CO;2-R

[34] Palmer, J.R., Boggs, D.A., Wise, L.A., Ambrosone, C.B., Adams-Campbell, L.L. and Rosenberg, L. (2011) Parity and Lactation in Relation to Estrogen Receptor Negative Breast Cancer in African American Women. Cancer Epidemiology, Biomarkers and Prevention, 20, 1883-1891. http://dx.doi.org/10.1158/1055-9965.EPI-11-0465

[35] Laamiri, F.Z., Hasswane, N., Kerbach, A., Aguenaou, H., Taboz, Y., Benkirane, H., Mrabet, M. and Amina, B. (2016) Risk Factors Associated with a Breast Cancer in a Population of Moroccan Women Whose Age Is less than 40 Years: A Case Control Study. The Pan African Medical Journal, 24, 19. http://dx.doi.org/10.11604/pamj.2016.24.19.8784

[36] Ortiz Mendoza, C.M. and Galván Martínez, E.A. (2007) [Reproductive Risk Factors of Breast Cancer in Patients Attended at a Second Level Urban Hospital]. Ginecologia y Obstetricia de Mexico, 75, 11-16. (In Spanish)

[37] Key, T.J., Verkasalo, P.K. and Banks, E. (2001) Epidemiology of Breast Cancer. Lancet On- 
cology, 2, 133-140. http://dx.doi.org/10.1016/S1470-2045(00)00254-0

[38] Laffoy, M., McCarthy, T., Mullen, L., Byrne, D. and Martin, J. (2013) Cancer Incidence and Mortality Due to Alcohol: An Analysis of 10-Years Data. Irish Medical Journal, 106, 294297.

[39] Qian, F., Ogundiran, T., Hou, N., Ndom, P., Gakwaya, A., Jombwe, J., Morhason-Bello, I., Adebamowo, C., Ademola, A., Ojengbede, O., Olopade, O.I. and Huo, D. (2014) Alcohol Consumption and Breast Cancer Risk among Women in Three Sub-Saharan African Countries. PLoS ONE, 9, e106908. http://dx.doi.org/10.1371/journal.pone.0106908

[40] American Cancer Society (2013) Breast Cancer Facts \& Figures 2013-2014. American Cancer Society, Inc., Atlanta

http://www.cancer.org/acs/groups/content/@research/documents/document/acspc-042725. pdf

[41] Canadian Cancer Society (2016) Risk Factors for Breast Cancer.

http://www.cancer.ca/en/cancer-information/cancer-type/breast/risks/?region=qc

Submit or recommend next manuscript to SCIRP and we will provide best service for you:

Accepting pre-submission inquiries through Email, Facebook, LinkedIn, Twitter, etc.

A wide selection of journals (inclusive of 9 subjects, more than 200 journals)

Providing 24-hour high-quality service

User-friendly online submission system

Fair and swift peer-review system

Efficient typesetting and proofreading procedure

Display of the result of downloads and visits, as well as the number of cited articles

Maximum dissemination of your research work

Submit your manuscript at: http://papersubmission.scirp.org/

Or contact ojog@scirp.org 